\title{
Protective Work Wear for Labour Working in Metal Electroplating Units: A Critical Review
}

\author{
Sugandha Sahni ${ }^{1}$, Dr. Rita Kant ${ }^{2}$, Prof. Dr M. S. Parmar ${ }^{3}$ \\ ${ }^{1}$ Assistant Professor, Amity School of Fashion Technology, Amity University, Noida, India \\ ${ }^{2}$ Assistant Professor Institute of Fashion Technology, Panjab University Chandigarh, India \\ Professor, NITRA, Ghaziabad, UP, India
}

\begin{abstract}
This paper is a summary of documented research on Chemical Protective Clothing worn by labour handling chemicals in metal electroplating industries. The reviewer has discussed the facts involved in the process of electroplating. There are numerous problems involved in the process of plating. It plays an important role in making a metal aesthetically usable. Metal Electroplating involves 4 steps/ stages and handling of chemicals like $\mathrm{H} 2 \mathrm{CrO4}, \mathrm{H} 2 \mathrm{SO} 4, \mathrm{Ni}(\mathrm{NH} 2 \mathrm{SO}$ )2, $\mathrm{HNH} 2 \mathrm{SO}$, acids and alkalis as shown in Table 1. In the process workers are likely to harm and injure themselves with strong fumes and direct contact with skin. Particular emphasis has been placed on the requirements, performance, standards and analysis of this protective wear. This article identifies domain for improving performance of protective wear and testing methods.
\end{abstract}

Keywords: CPC, Chemical Hazards, Standards, Requirements, OSHA, NFPA

\section{Introduction}

Electroplating is one of the varieties of several techniques of metal finishing. It is a technique of deposition of a fine layer of one metal on another through electrolytic process to impart various properties and attributes, such as corrosion protection, enhanced surface hardness, lustre, color, aesthetics, value addition etc. The electroplating industry has been playing a great role in development and growth of numerous metal manufacturing and other engineering industries. While electroplating operations are an essential and integral part of many engineering industries, there has also been a steady growth of independent and tiny - to medium-scale electroplating industries. The growth of these independent small scale electroplating industries may be attributable to the growth of light and medium engineering industries which found it more convenient and economical to have their products metal plated by independent electroplaters. Electroplating industry in India is spread throughout the country. They are mainly in small scale sectors with over 3,00,000 small scale units. There are huge numbers of workers employed in these units. There are a number of problems associated with units. But pollution and health hazards are the prominent problems. A lot of work is going on to control pollution created by these industries. Workers at electroplating workplaces may be exposed to hazardous chemicals in the form of fumes, vapours, mists, metal dusts, electrolytic solutions, acids \& alkalis, solvents, heavy metals (like nickel $(\mathrm{Ni})$, hexavalent chromium (chrome VI, CrVI) and cadmium (Cd) compounds) and toxic wastes. Exposure to chemical hazards may cause short and/or long term health problems including skin and eye irritation, burns, asthma/breathing problems, nerve disorders, and in some cases, cancer. Some of these health related hazards can be reduced by providing suitable work wear to the workers. ${ }^{(20)}$ This paper describes the health hazard chemicals used in the electroplating units, need of work wear and their performance as per national and international standards.

\section{Review of Literature}

\section{Occupational health hazards}

Occupational health refers to the identification and control of the risks arising from physical, chemical, and other workplace hazards in order to establish and maintain a safe and healthy working environment. These hazards may include chemical agents and solvents, heavy metals such as lead and mercury, physical agents such as loud noise or vibration, and physical hazards such as electricity or dangerous machinery.

As per the Director General of Factory Advisory Services and Labour Institutes Report (1998), there were 300,000 registered industrial factories and more than 5000 chemical factories in India, employing over half a million workers. Approximately 8.8 million workers were employed in various factories. ${ }^{(18)}$ In India, occupational health is more than simply a health issue, which includes child labour, poor industrial legislation, vast informal sector, less attention to industrial hygiene and poor surveillance data. ${ }^{(10)}$ Statistics for the overall incidence and prevalence of occupational disease and injuries for the country is inadequate. According to Leigh et al. ${ }^{(13)}$, the annual incidence of occupational disease was between 924,700 and $1,902,300$, leading to over 121,000 deaths in India.

Srivastava (2002) in a paper on "Occupational Health of Workers in India Law and Practice" focuses on the modernisation and innovation in industries and rapid increase in chemical, hazardous, and polluting industries in recent years. The paper reveals that this has not only resulted in unsafe working conditions but has also created problems of occupational health hazards. The incidence of occupational diseases is much higher in developing countries than developed ones, although no region of the world is immune from this. In developing countries the workers most exposed to occupational risks are those employed in agriculture, chemical and primary extraction industries and heavy manufacturing. Quite apart from working with poor equipment, heavy workload and even poisoning due to 


\section{International Journal of Science and Research (IJSR) \\ ISSN (Online): 2319-7064}

Index Copernicus Value (2013): 6.14 | Impact Factor (2014): 5.611

pesticides and organic dusts take a heavy toll on workers health and safety. ${ }^{(21)}$

Mauskar (2008) in a newsletter Parivesh by Central Pollution Control Board, Delhi on Waste Minimisation and EcoFriendly Electroplating Processes points out that a wide variety of chemicals and substances are used by the industry depending on the surface properties of the objects to be electroplated. The basic electroplating system consists of a plating bath filled with water containing a small amount of acid or alkali added to improve its conductivity. In brass plating, usually a cyanide bath is used, which comprises $\mathrm{Cu}(\mathrm{CN})_{2}, \mathrm{NaCN}, \mathrm{Zn}(\mathrm{CN})_{2}$ and $\mathrm{Na}_{2} \mathrm{CO}_{3}$. Zinc plating also requires acid cyanide and alkaline cyanide. The chemicals used in various electroplating operations are numerous. These chemicals can be classified generally as acids and alkalis for cleaning purpose, inorganic chemicals, and organic chemicals which help in achieving certain properties or to enhance the process of plating. Cyanide is extremely toxic to humans. Acute (short-term) inhalation exposure to 100 milligrams per cubic meter or more of hydrogen cyanide can cause death in humans. ${ }^{(15)}$

Khan, Halim \& Iqbal (2006) conducted a survey on workers as well as on some management personnel of Natural Gas Fertilizer Companies in Bangladesh in 2002-2003 to find out the attributes of occupational injury among workers in the chemical industry and safety issues. They collected data based on injury and existing safety conditions. Injury data were collected and processed in terms of different variables, such as age, gender, skill, type of hazard. Pareto analysis was then applied to find a pattern of occupational injury among the workers. The study revealed that $79.52 \%$ of the injured workers were in the age of 40-59 age group, $73.26 \%$ of accidents caused injury to hands, feet, chest to thigh, arms, and eyes. The chemical hazards caused are $27.91 \%$ of total injuries. ${ }^{(12)}$

\section{Hazardous Chemicals}

There are a number of chemicals which are being used in the electroplating units which affect the health of workers adversely. Beside this adverse health effects due to exposure to hazardous chemicals are also dependent on the type and amount of contact, the duration of exposure and the route of entry into the body. As per 'Safe Work Australia' document (www.safeworkaustralia.gov.au) ${ }^{(16)}$ exposure to hazardous chemicals in an electroplating workplace can occur:

- When containers leak or spill during transport, storage, decanting or disposal

- If fumes or gases build up during storage or use in confined or inadequately ventilated areas

- During the electroplating process (splashing when placing or removing items in the tank, from metal or acid aerosols as a result from excessive bubbling or fuming in electrolytic solutions)

- If extraction systems removing corrosive mists or toxic gases fail, are inadequate or improperly designed or installed

- If there is inadequate housekeeping (drips and spills, incorrect disposal of wastes, poor clean up procedures causing incidental contact with contaminated surfaces) during cleaning, maintenance or repair of tanks
- If toxic gases are released due to accidental mixing of incompatible chemicals

- If personal protective equipment is inadequate

- Through skin contact with contaminated personal protective equipment.

During the process of electroplating various chemicals are used and some of hazardous chemicals are generated during processing. Some of these chemicals are discussed below:

1) Acids: the method of electroplating started with dipping material into varied sorts of acids as per the necessity. A number of these acids such as hydrochloric, hydrofluoric, sulphuric and nitrous acids are corrosive to the skin and eyes.

2) Acid mists are also evolved from high concentrations of acid, air or tank content agitation or elevated tank temperatures. Acid mists irritate the skin, eye, nose and throat, and end up hurting, cough and shortness of breath. The workers may get harmed during the processing of these acids. Sometimes acids also get spilled due to accidents.

3) Arsine Gas: Sometimes there is presence of arsenic ions in the solution used for electroplating. These may be present as an impurity in metal or in commercial grade hydrochloric and sulphuric acids. In the presence of acids and nascent hydrogen, they form Arsine gas. Arsenic poisoning can be acute due to its haemolytic activity, or chronic due to its carcinogenic potential. Symptoms include headache, dizziness, abdomen pains, nausea, restlessness, seizure and coma.

4) Chromic Acid: Chromic acid contains soluble hexavalent chromium which is poisonous and carcinogenic. Chromic acid is a strong irritant and corrosive. Exposure generally arises as the end result of:

- Splashes

- As a vapour of chromic acid coated bubbles of hydrogen

- As chromic acid soiled dust.

5) Cyanide: The cyanide solution contains cyanide ions which are corrosive to skin and eyes and if swallowed highly toxic. If the $\mathrm{pH}$ of a cyanide plating bath falls below approximately $\mathrm{pH} 10$, the air above the bath may surround high degree of hydrogen cyanide gas. This will also happen when cyanide ions move towards an acid. Hydrogen cyanide gas smells of bitter almonds and as a chemical asphyxiant is one of the most rapidly acting of all identified poisons.

6) Not all people are able to distinguish the odour and trust on the sense of smell should not be used as a warning signal. Symptoms of cyanide poisoning include weakness, confusion, and shortness of breath, headache, giddiness, seizures and unconsciousness.

7) Dusts: Grinding or polishing machines are used for the grinding, polishing and buffing of metal objects by means of an abrasive wheel, scratch-brush wheel, grinding and finishing belt or other similar equipment. When used in conjunction with abrasive polishes, these produce fine dusts and should have a competent local ventilation system or a dust extraction system fitted. Extended exposure to such dusts can lead to pneumoconiosis with symptoms including inflammatory reactions within the lungs, coughing, chest tightness and shortness of breath. 


\section{International Journal of Science and Research (IJSR) ISSN (Online): 2319-7064 \\ Index Copernicus Value (2013): 6.14 | Impact Factor (2014): 5.611}

8) Solvents: Most solvents used in electroplating pretreatment processes are organic chlorine, alcohol or petroleum based chemicals which have powerful properties to dissolve organic solids. They are often mixture of several chemicals and can be particularly hazardous. Commonly used hazardous solvents in electroplating include acetone and trichloroethylene.

Solvents can enter through skin, may be inhaled, ingested or absorbed. They can cause short term adverse health effects such as dermatitis including drying, cracking, reddening or blistering of the skin, headaches and drowsiness, poor coordination, and nausea. Exposure to high concentrations of solvent vapour can lead to unconsciousness and death.

Long term health effects from solvent exposure include effects on the brain and nervous system, the skin, liver, bonemarrow, kidneys, fertility and the foetus, and some solvents are carcinogenic.

Some solvents have synergistic effects. This means that they will have greater health effects in combination with other hazards. For example when using some organic solvents, adverse health effects will be greater if you smoke cigarettes or drink alcohol soon after handling. ${ }^{(11)}$

A list of chemicals being used in the electroplating units is also shown in Table-1.

Sadhra (2002) et al studied workers' understanding of chemical risks at electroplating units at West Midlands, England. In their study they compared the responses of electroplater with the occupational health and safety experts. The chromium platers could understand the short term damage they were facing but failed to understand long term consequences. They were aware of hazardous nature of chemicals but failed to draw distinction between "hazards" and "risks". The workers were not the native speakers of English. Majority of them spoke Punjabi as it was their first language. The platers never used specific names, they only mentioned generic names. The results showed that $89 \%$ of platers accepted that these chemicals are carcinogic. The major difference between experts and electroplaters was the knowledge of technical terms as respiratory, carcinogen, sensitisation by skin contact. The electroplaters feel that PPE is the first thing which can safeguard them whereas the experts feel that it is the last line of defence. ${ }^{(19)}$

Halliday-Bell, J. Conducted a study on health and safety behaviour and compliance on electroplating workshops at Dorset, UK. They surveyed all nickel and chrome plating units and checked health and safety training, awareness and behaviour of employees. $60 \%$ of the workers faced occupational skin disease. $80 \%$ of the employees failed to do basic skin care program. The workers were aware of PPE but did not wear it always. They stressed on the urgent need on the requirement to improve the training of employees and to explain them of the consequences of their default. It is equally important that personal protective equipment is worn, maintained and kept free from contamination. ${ }^{(7)}$

In a workbook on Hexanalent Chromium by Occupational Health Clinics for Ontario Workers Inc. in 2005 explained how hexavalent chromium can enter the body by swallowing contaminated dust or if dust particles stick to the cloth or beard. It can also enter by breathing contaminated air in form of fumes or mist. The hexavalent chromium has been classified as the human carcinogen by U.S Environmental Protection Agency and the International Agency for Research on cancer. Cr-6 compounds are respiratory tract and major skin irritant. It can irritate the broken skin turning into ulcers and also prolonged exposures can result in asthmatic problems. Direct eye contact with chromic acid can damage eye permanently. The PPE worn by platers must be tested especially in case of respirators; they should fit the workers face. The worker should be trained how to use the respirator.

Gibb et al (2002) explained that if there is any skin contact with material containing $\mathrm{Cr}_{6}$ there is risk of dermal exposure on splashing, spilling. In welding, steel, tannery and other industries have reported of dermal exposures. ${ }^{(5)}$

Karthik et al (2014) studied effect of hexavalent chromium exposures and control measures through phytoremediation. There are two potential exposures through chromium i.e. air born and dermal. Hexavalent is one of the 20 chemicals which are assessed for risk. There is risk of lung cancer when it is swallowed in human body. The soil which is polluted is a problem for both the ecosystem and land development. Phytoremediation is the method in which more of the green plants are grown in polluted soil. ${ }^{(11)}$

\section{Requirement of Protective equipment}

Personal Protective Equipment can be worn on any site where respiratory or skin hazards exist. PPE is designed to provide protection from serious injuries or illnesses resulting from contact with chemical, radiological, physical, electrical, mechanical, or other hazards. Careful selection and use of adequate PPE should protect individuals involved in chemical emergencies from hazards effecting the respiratory system, skin, eyes, face, hands, feet, head, body, and hearing. No single combination of protective equipment and clothing is capable of protecting against all hazards. Thus PPE should be used in conjunction with other protective methods, including exposure control procedures and equipment.

Gopalakrishnan (2002) explains protective materials as those materials that have principal protection property of being ballistic resistive, puncture resistive, nuclear resistive, biological resistive, chemical resistive, and any combination of these properties. There is no material which is completely resistible. Materials only temporarily resist chemical breakthrough; even the most chemically resistant material also gets weakened over a period of time. The most appropriate clothing should have no penetration, no significant degradation and a low permeation level once it is in contact with chemicals. In his study he designed and developed chemical protective clothing to suit these requirements. A fabric was formed with activated carbon granules with a needle punching technique. The results showed that in case of acetone the penetration was $0.4 \%$ and there was no penetration in case of hydrogen peroxide and sodium hydroxide. There was no permeation in case of sulphuric acid but the amount of degradation was high and fabric weight loss was of $18.60 \%{ }^{(6)}$ 


\section{International Journal of Science and Research (IJSR) \\ ISSN (Online): 2319-7064}

Index Copernicus Value (2013): 6.14 | Impact Factor (2014): 5.611

According to US Department of Health and Human Services there are four categories based on the degree of protection:

- Level A protection is the highest level of protection. It is worn when there is a need for protecting eyes, skin, respiratory and mucous membrane.

- Level B protection serves when highest level of respiratory protection is required, but a comparatively lower level of skin and eye protection is needed.

- Level C protection should be selected when skin and eye exposure is unlikely and the type of airborne substance is known.

- Levels D protection is particularly a work wear uniform used for trouble contamination only. It requires only coveralls and safety shoes/boots.

OSHA is part of the United States Department of Labor. OSHA stands for Occupational Safety and Health Administration. In its manual it has provided factors for selecting PROTECTIVE CLOTHING. The main factors are Clothing Design, Chemical Resistant Material, Physical Properties, Ease of Determination, Cost and Chemical Protective Standards. ${ }^{(17)}$

\section{A. Clothing Design}

The Manufacturers sell clothing in a range of styles and configuration. The Design Considerations for protective clothing are:

- Clothing configuration: this depends on the type of work the labour is doing. Ease of movement and manoeuvrability is affected by style and shape of clothing.

- Components: all elements such as fasteners like buttons zippers and velcros as also placement of plackets and pockets should be aptly set and fixed.

- Sizes: protective clothing is mainly available in three sizes namely: Small, Medium and Large.

- Ease of donning and doffing: ease to put on and off.

- Clothing construction: seam finishes should be such that seam seepage is minimal.

- Comfort: the overall or cover-all should be comfortable to wear. There can be atmospheric changes at the worksite so the clothing should suit the working conditions.

- Mobility: the worker or labour working in industry is required to do certain tasks so his mobility to perform these tasks is utmost important and must be given high priority.

B. Chemical Resistance Material. The chosen material(s) must resist permeation, degradation, and penetration by the respective chemicals.

(i) Permeation: The most suitable method of assessing material chemical compatibility is through permeation break through time. It is the process by which a chemical dissolves in or moves into a material on a molecular basis. The rate of permeation depends on several factors such as chemical concentration, material thickness, humidity, temperature, and pressure. To test a material, it is exposed to a chemical over an extended exposure period. The time it takes for the chemical to permeate through the material is the breakthrough time. A suitable material is one where the breakthrough time goes above the expected period of garment use. However, temperature and pressure effects may enhance permeation and reduce the magnitude of this safety factor. For example, small increases in ambient temperature can significantly reduce breakthrough time and the protective barrier properties of a protective clothing material.

(ii) Degradation involves physical changes in a material as a result of chemical exposure, use and ambient conditions. The most common observations of material degradation are discoloration, swelling, loss of physical strength, or deterioration.

(iii) Penetration is the seepage of chemicals through zippers, seams, or imperfections in a protective clothing material.

No material protects against all chemicals and combinations of chemicals. At present there are no known available materials that give an effective barrier from prolonged chemical exposure.

\section{Physical Properties}

Manufacturers of materials offer wide ranges of physical qualities in terms of strength, resistance to physical hazards, and operation in extreme environmental conditions. Fabric quality, garment designs and seams provide physical integrity and comfort. Comprehensive manufacturing standards like NFPA (National Fire Protection Association) Standards set specific limits on these material properties. These materials however have limited applications and may work only as "emergency response".

End users can assess material physical properties such as to withstand the physical strength of the tasks at hand, resist tears, cuts, and abrasion, withstand repeated use after contamination and decontamination, material flexibility or pliability, protective integrity and flexibility under hot and cold extremes, be flame-resistant or self-extinguishing.

\section{Ease of Determination.}

The degree of difficulty in decontaminating protective clothing may dictate whether disposable or reusable clothing or a combination of both should be used.

\section{E. Cost}

Protective clothing end users must attempt to obtain the broadest protective equipment they can buy with available resources to meet their specific demand.

\section{F. Chemical Protective Clothing Standards}

Protective clothing buyers may wish to specify clothing that meets specific standards, such as 1910.120(Occupational Safety and Health Standards for Hazardous waste operations and emergency response) or the NFPA standards. The NFPA Standards do not apply to all forms of protective clothing and applications.

The requirement of chemical protective clothing varies from standard to standard. A brief of standards is given in Table 3. In India, IS-15071standard is given for protection against chemicals. This standard gives prerequisite and methods of sampling and tests for chemical protective clothing. It also provides guidance for the selection of clothing and basic requirements for the fabric which intends to protect skin against contact to chemicals. BIS has defined Chemical Protective Clothing as: "A garment which covers or replaces personal clothing, and which is designed to provide 


\section{International Journal of Science and Research (IJSR) \\ ISSN (Online): 2319-7064}

Index Copernicus Value (2013): 6.14 | Impact Factor (2014): 5.611

protection against one or more chemicals". It explains Breakthrough Time as: "The elapsed time between the initial application of a chemical to the appropriate surface of the material and its subsequent presence on the other side of the material". It defines a Total Protection Suit as: "A Chemical protective suit combining eye/face protection, respiratory protection, hand protection, body protection, and leg /feet protection into one full-body covering". It classifies the protective clothing into four types based on the breakthrough time. Type 1 is for breakthrough time over 6 hours, type 2 is from 2 hours to 6 hours, type 3 is from $12 \mathrm{~min}$ to 2 hours, and type 4 is for just up to $12 \mathrm{mins}$ i.e. remove as soon as possible if contaminated. ${ }^{(2)}$

Li et al (2013) did a comparative study of Chinese and International Standard Systems on Chemical Protective Clothing. They found that 6 Standard systems; 44 standards of CPC, 14 of ASTM and 11 of EN are largely used, followed by 9 of ISO standards, 5 of JIS standards, 4 of GB and 1 of BS. ASTM and JIS Standards focus on Test Methods for resistance to permeation and how to wear and maintain CPC and do not provide any specifications for performance. The comparative analysis of China's National Standards and International Standard Systems for CPC show the most basic performance assessment factors for all types of CPC. These are tensile strength, trapezoidal tear resistance, puncture resistance, bursting resistance, abrasion resistance, flex cracking resistance and flex cracking resistance at low temperatures $\left(-30^{\circ} \mathrm{C}\right)$. The EN and ISO standards include additional assessment factors. For many performance assessment factors EN set higher requirements than ISO. ${ }^{(14)}$

To protect worker, working in the electroplating units, it is needed to provide them various protective equipments. Some of them are discussed below:

Gloves: The worker should be provided with gloves up to elbow length and should be made of such a type of material, which does not affect with various acids and others chemicals.

Clothing and face protection: Overalls must be provided and changed regularly to prevent skin contact with hazardous substances. Impervious aprons should be worn over overalls to protect workers from splashes of tank solutions. Beside this safety hazards of a chemical include its flammability and reactivity. Flammability is the tendency of a chemical to burn. Solvents are common flammable chemicals in an electroplating workplace. Reactivity is the potential of the material to explode or react violently with air, water or other

substances upon contact. Some metal dusts produced during buffing and grinding may create an explosion hazard if there is an ignition source. Therefore work wear should also have property to save worker from fire accident. Suitable acidresistant footwear with hard toe-caps should be provided. A visor, face shield or well-fitting goggles must be worn if there is a risk of splashes on the face. Protective equipment should be washed daily.

Respirators: Respirators should be available to all workers for use during various operations of electroplating.

Table 1: Chemicals Being Used in Metal Electroplating Units

\begin{tabular}{|l|l|l|}
\hline S. No. & Chemicals & Class \\
\hline 1 & $\mathrm{Ni}\left(\mathrm{NH}_{2} \mathrm{SO}_{3}\right)_{2}$ & Acid \\
\hline 2 & $\mathrm{HNH}_{2} \mathrm{SO}_{3}$ & Acid \\
\hline 3 & $\mathrm{H}_{2} \mathrm{C}_{2} \mathrm{O}_{4}$ & Acid \\
\hline 4 & $\mathrm{NaF}$ & Acid \\
\hline 5 & $\mathrm{H}_{2} \mathrm{SO}_{4}$ & Acid \\
\hline 6 & $\mathrm{Cu}_{2} \mathrm{P}_{2} \mathrm{O}_{7}$ & Alkali \\
\hline 7 & $\mathrm{HCl}$ & Acid \\
\hline 8 & $\mathrm{NaOH}$ & Alkali \\
\hline 9 & $\mathrm{HNO}_{3}$ & Acid \\
\hline
\end{tabular}

Table 2: Source: OSHA Technical Manual (OTM) Section VIII: Chapter 1(2009)

\begin{tabular}{|c|c|}
\hline Chemical & Class \\
\hline $\begin{array}{l}\text { Acetone } \\
\text { Acetonitrile } \\
\text { Ammonia } \\
\text { 1,3-Butadiene } \\
\text { CarbonDisulfide } \\
\text { Chlorine } \\
\text { Dichloromethane } \\
\text { Diethylamine } \\
\text { Dimethyl formamide } \\
\text { Ethyl Acetate } \\
\text { Ethyl Oxide } \\
\text { Hexane } \\
\text { Hydrogen Chloride } \\
\text { Methanol } \\
\text { Methyl Chloride } \\
\text { Nitrobenzene } \\
\text { Sodium Hydroxide } \\
\text { Sulphuric Acid } \\
\text { Tetrachloroethylene } \\
\text { Tetrahydrofuran } \\
\text { Toluene }\end{array}$ & $\begin{array}{l}\text { Ketone } \\
\text { Nitrile } \\
\text { Strong base (gas) } \\
\text { Olefin (gas) } \\
\text { Sulphur-containing organic } \\
\text { Inorganic gas } \\
\text { Chlorinated hydrocarbon } \\
\text { Amine } \\
\text { Amide } \\
\text { Ester } \\
\text { Oxygen heterocyclic gas } \\
\text { Aliphatic hydrocarbon } \\
\text { Acid gas } \\
\text { Alcohol } \\
\text { Chlorinated hydrocarbon } \\
\text { (gas) } \\
\text { Nitrogen-containing organic } \\
\text { Inorganic base } \\
\text { Inorganic acid } \\
\text { Chlorinated hydrocarbon } \\
\text { Oxygen heterocyclic } \\
\text { Aromatic hydrocarbon }\end{array}$ \\
\hline
\end{tabular}

Table 3: Various Standard Systems for Chemical Protective Clothing followed Worldwide

\begin{tabular}{|c|c|c|c|}
\hline Name of Standard & $\begin{array}{c}\text { Year } \\
\text { Founded }\end{array}$ & $\begin{array}{c}\text { Test methods and } \\
\text { Performance } \\
\text { Requirements }\end{array}$ & Description \\
\hline $\begin{array}{c}\text { American Society for } \\
\text { Testing and Material } \\
\text { (ASTM) }\end{array}$ & 1898 & F903-10 & $\begin{array}{c}\text { Standard Test Method for Resistance of Materials Used in } \\
\text { Protective Clothing to Penetration by Liquids }\end{array}$ \\
\cline { 3 - 4 } & & F1001-12 & $\begin{array}{c}\text { Standard Guide for selection of chemicals to evaluate } \\
\text { protective clothing materials }\end{array}$ \\
\cline { 3 - 4 } & F1194-99(2010) & $\begin{array}{c}\text { Standard Guide for documenting the results of chemical } \\
\text { permeation testing of materials used in protective clothing }\end{array}$ \\
\cline { 3 - 4 } & F1296-08(2015) & Standard Guide for evaluating chemical protective clothing \\
\cline { 3 - 4 } & F1301-90(2011)e1 & Standard Practice for labelling chemical protective clothing \\
\hline
\end{tabular}

\section{Volume 4 Issue 12, December 2015}


International Journal of Science and Research (IJSR)

ISSN (Online): 2319-7064

Index Copernicus Value (2013): 6.14 | Impact Factor (2014): 5.611

\begin{tabular}{|c|c|c|c|}
\hline & & F1359/F1359M-13 & $\begin{array}{c}\text { Standard Test Method for Liquid Penetration Resistance of } \\
\text { Protective Clothing or Protective Ensembles Under a Shower } \\
\text { Spray While on a Mannequin }\end{array}$ \\
\hline & & F1383-12e1 & $\begin{array}{l}\text { Standard Test method for permeation of liquids and gases } \\
\text { through protective clothing materials under conditions of } \\
\text { intermittent contact }\end{array}$ \\
\hline & & F1407-12 & $\begin{array}{l}\text { Standard Test Method for Resistance of Chemical Protective } \\
\text { Clothing Materials to Liquid Permeation--Permeation Cup } \\
\text { Method }\end{array}$ \\
\hline & & F1461 & Standard Practice for chemical protective program \\
\hline & & F2061-12 & $\begin{array}{c}\text { Standard Practice for chemical protective clothing: wearing, } \\
\text { care, and maintenance instructions }\end{array}$ \\
\hline & & F2815-10(2014) & $\begin{array}{l}\text { Standard practice for chemical permeation through protective } \\
\text { clothing materials: testing Data Analysis by use of a computer } \\
\text { program }\end{array}$ \\
\hline & & F739-12e1 & $\begin{array}{l}\text { Standard Test Method for Permeation of Liquids and Gases } \\
\text { through Protective Clothing Materials under Conditions of } \\
\text { Continuous Contact }\end{array}$ \\
\hline & & F2130-11 & $\begin{array}{c}\text { Standard Test Method for Measuring Repellency, Retention, } \\
\text { and Penetration of Liquid Pesticide Formulation Through } \\
\text { Protective Clothing Materials }\end{array}$ \\
\hline & & F2053-00(2011) & $\begin{array}{c}\text { Standard Guide for Documenting the Results of Airborne } \\
\text { Particle Penetration Testing of Protective Clothing Materials }\end{array}$ \\
\hline & & F2669-12 & $\begin{array}{c}\text { Standard Performance Specification for Protective Clothing } \\
\text { Worn by Operators Applying Pesticides }\end{array}$ \\
\hline
\end{tabular}

\begin{tabular}{|c|c|c|c|}
\hline Name of Standard & $\begin{array}{c}\text { Year } \\
\text { Founded }\end{array}$ & $\begin{array}{l}\text { Test methods and } \\
\text { Performance } \\
\text { Requirements }\end{array}$ & Description \\
\hline \multirow[t]{8}{*}{$\begin{array}{ll}\begin{array}{l}\text { European } \\
(\mathrm{EN})^{(4)}\end{array} & \text { Standards } \\
\end{array}$} & \multirow[t]{8}{*}{1961} & BS EN 943-1: 2002 & $\begin{array}{l}\text { Protective clothing against liquid and gaseous chemicals, } \\
\text { including liquid aerosols and solid particles - Part 1: } \\
\text { Performance requirements for ventilated and non-ventilated } \\
\text { "gas-tight" (Type 1) and "non-gas-tight" (Type 2) chemical } \\
\text { protective suits }\end{array}$ \\
\hline & & BS EN 943-2: 2002 & $\begin{array}{l}\text { Protective clothing against liquid and gaseous chemicals, } \\
\text { including liquid aerosols and solid particles - Part 2: } \\
\text { Performance requirements for "gas-tight" (Type 1) } \\
\text { chemical protective suits for emergency teams (ET) }\end{array}$ \\
\hline & & BS EN 464:1994 & $\begin{array}{l}\text { Protective clothing - Protection against liquid and gaseous } \\
\text { chemicals, including aerosols and solid particles - Test } \\
\text { method: Determination of leak-tightness of gas-tight suits } \\
\text { (Internal pressure test) }\end{array}$ \\
\hline & & BS EN 14325: 2004 & $\begin{array}{l}\text { Protective clothing against chemicals-test methods and } \\
\text { performance classification } \\
\text { of chemical protective clothing materials, seams, joins and } \\
\text { assemblages. }\end{array}$ \\
\hline & & BS EN 463: 1995 & $\begin{array}{l}\text { Protective clothing-protection against liquid chemicals-test } \\
\text { method: determination } \\
\text { of resistance to penetration by a jet liquid (jet test). }\end{array}$ \\
\hline & & BS EN 468: 1995 & $\begin{array}{l}\text { Protective clothing-protection against liquid chemicals-test } \\
\text { method: determination } \\
\text { of resistance to penetration by spray (spray test) }\end{array}$ \\
\hline & & BS EN 13034:2005 & $\begin{array}{l}\text { Protective clothing against liquid chemicals- performance } \\
\text { requirements for chemical protective clothing offering } \\
\text { limited protective performance against liquid chemicals }\end{array}$ \\
\hline & & BS EN 14605: 2005 & $\begin{array}{l}\text { Protective clothing against liquid chemicals-performance } \\
\text { requirements for clothing } \\
\text { with liquid-tight (type } 3 \text { ) or spray-tight (type 4) } \\
\text { connections, including items providing protection } \\
\text { to parts of the body only (types PB[3] and PB[4]) }\end{array}$ \\
\hline British Standards (BS) & 1901 & BS 8428-2004 & $\begin{array}{l}\text { Protective clothing-Protection against liquid chemicals- } \\
\text { Performance requirements for } \\
\text { chemical protective suits with liquid-tight connections } \\
\text { between different parts of the clothing for emergency teams } \\
\text { (type 3-ET equipment) }\end{array}$ \\
\hline
\end{tabular}

Volume 4 Issue 12, December 2015

www.ijsr.net

Licensed Under Creative Commons Attribution CC BY 
International Journal of Science and Research (IJSR)

ISSN (Online): 2319-7064

Index Copernicus Value (2013): 6.14 | Impact Factor (2014): 5.611

\begin{tabular}{|c|c|c|c|}
\hline Name of Standard & $\begin{array}{c}\text { Year } \\
\text { Founded }\end{array}$ & $\begin{array}{l}\text { Test methods and } \\
\text { Performance } \\
\text { Requirements }\end{array}$ & Description \\
\hline \multirow[t]{15}{*}{$\begin{array}{l}\text { International } \\
\text { Organization for } \\
\text { Standardization (ISO) }\end{array}$} & \multirow[t]{15}{*}{1947} & ISO $6529: 2013$ & $\begin{array}{l}\text { Protective clothing -- Protection against chemicals -- } \\
\text { Determination of resistance of protective clothing materials } \\
\text { to permeation by liquids and gases }\end{array}$ \\
\hline & & 6530:2005 & $\begin{array}{l}\text { Protective clothing -- Protection against liquid chemicals -- } \\
\text { Test method for resistance of materials to penetration by } \\
\text { liquids }\end{array}$ \\
\hline & & ISO/CD & $\begin{array}{l}\text { Protective clothing -- Protection against liquid chemicals -- } \\
\text { Measurement of cumulative permeation of chemicals with } \\
\text { low vapour pressure through protective clothing and glove } \\
\text { materials }\end{array}$ \\
\hline & & 22608:2004 & $\begin{array}{l}\text { Protective clothing -- Protection against liquid chemicals -- } \\
\text { Measurement of repellency, retention, and penetration of } \\
\text { liquid pesticide formulations through protective clothing } \\
\text { materials }\end{array}$ \\
\hline & & $27065: 2011$ & $\begin{array}{l}\text { Protective clothing }-- \text { Performance requirements for } \\
\text { protective clothing worn by operators applying liquid } \\
\text { pesticides }\end{array}$ \\
\hline & & 13994:2005 & $\begin{array}{l}\text { Clothing for protection against liquid chemicals -- } \\
\text { Determination of the resistance of protective clothing } \\
\text { materials to penetration by liquids under pressure }\end{array}$ \\
\hline & & ISO 17491-1:2012 & $\begin{array}{l}\text { Protective clothing -- Test methods for clothing providing } \\
\text { protection against chemicals -- Part 1: Determination of } \\
\text { resistance to outward leakage of gases (internal pressure } \\
\text { test) }\end{array}$ \\
\hline & & ISO/CD 17491-2 & $\begin{array}{l}\text { Protective clothing -- Test methods for clothing providing } \\
\text { protection against chemicals -- Part 2: Determination of } \\
\text { resistance to inward leakage of aerosols and gases (inward } \\
\text { leakage test) }\end{array}$ \\
\hline & & ISO 17491-3:2008 & $\begin{array}{l}\text { Protective clothing -- Test methods for clothing providing } \\
\text { protection against chemicals -- Part 3: Determination of } \\
\text { resistance to penetration by a jet of liquid (jet test) }\end{array}$ \\
\hline & & ISO 17491-4:2008 & $\begin{array}{l}\text { Protective clothing -- Test methods for clothing providing } \\
\text { protection against chemicals -- Part 4: Determination of } \\
\text { resistance to penetration by a spray of liquid (spray test) }\end{array}$ \\
\hline & & ISO 17491-5:2013 & $\begin{array}{l}\text { Protective clothing -- Test methods for clothing providing } \\
\text { protection against chemicals -- Part 5: Determination of } \\
\text { resistance to penetration by a spray of liquid (manikin } \\
\text { spray test) }\end{array}$ \\
\hline & & ISO 13688:2013 & Protective clothing -- General requirements \\
\hline & & ISO 13982-1:2004 & $\begin{array}{l}\text { Protective clothing for use against solid particulates -- Part } \\
\text { 1: Performance requirements for chemical protective } \\
\text { clothing providing protection to the full body against } \\
\text { airborne solid particulates (type } 5 \text { clothing) }\end{array}$ \\
\hline & & ISO 13982-2:2004 & $\begin{array}{l}\text { Protective clothing for use against solid particulates -- Part } \\
\text { 2: Test method of determination of inward leakage of } \\
\text { aerosols of fine particles into suits }\end{array}$ \\
\hline & & ISO 16602:2007 & $\begin{array}{l}\text { Protective clothing for protection against chemicals -- } \\
\text { Classification, labelling and performance requirements }\end{array}$ \\
\hline
\end{tabular}

\begin{tabular}{|c|c|c|l|}
\hline $\begin{array}{c}\text { Name of } \begin{array}{c}\text { Standard } \\
\text { Founded }\end{array} \\
\begin{array}{c}\text { Japanese } \\
\text { Industrial } \\
\text { Standards (JIS) }\end{array}\end{array}$ & $\begin{array}{c}\text { Year methods and } \\
\text { Performance } \\
\text { Requirements }\end{array}$ & \multicolumn{1}{c|}{ Description } \\
\cline { 3 - 4 } & 1921 & JIS T8030-2005; & $\begin{array}{l}\text { Protective clothing- protection against chemicals-determination of } \\
\text { resistance of protective clothing materials to permeation by liquids and } \\
\text { gases. }\end{array}$ \\
\cline { 3 - 4 } & JIS T 8005:2005 & Protective Clothing- General Requirements \\
\cline { 3 - 4 } & JIS T8032-2005; & $\begin{array}{l}\text { Protective clothing-protection against gaseous and liquid chemicals- } \\
\text { determination } \\
\text { Of resistance of protective clothing to penetration by liquids and gases. }\end{array}$ \\
\cline { 3 - 4 } & JIS T8031-2010; & $\begin{array}{l}\text { Clothing for protection against liquid chemicals-determination of the } \\
\text { resistance of } \\
\text { Protective clothing materials to penetration by liquids under pressure. }\end{array}$ \\
\cline { 3 - 4 } & JIS T8115-2010 & Protective clothing for use against chemicals. \\
\hline
\end{tabular}

Volume 4 Issue 12, December 2015

www.ijsr.net

Licensed Under Creative Commons Attribution CC BY 


\section{International Journal of Science and Research (IJSR) \\ ISSN (Online): 2319-7064}

Index Copernicus Value (2013): 6.14 | Impact Factor (2014): 5.611

\begin{tabular}{|c|c|c|l|}
\hline \multirow{2}{*}{} & \multirow{2}{*}{} & JIS T 8034:2008 & $\begin{array}{l}\text { Protective clothing -- Protection against liquid chemicals -- } \\
\text { Measurement of repellency, retention, and penetration of liquid } \\
\text { pesticide formulations through protective clothing materials }\end{array}$ \\
\cline { 3 - 4 } & JIS T 8124:2010 & $\begin{array}{l}\text { Protective clothing for use against solid particulates -- Part 1: } \\
\text { Performance requirements for chemical protective clothing providing } \\
\text { protection to the full body against airborne solid particulates (type } \\
5 \text { clothing) }\end{array}$ \\
\cline { 3 - 4 } & JIS T 8124-2:2008 & $\begin{array}{l}\text { Protective Clothing for use against solid particulates -- Part 2: Test } \\
\text { method of determination of inward leakage of aerosols of fine particles } \\
\text { into suits }\end{array}$ \\
\hline $\begin{array}{c}\text { China's Guo Biao } \\
\text { (GB) }\end{array}$ & 1957 & GB/T 24539-2009; & $\begin{array}{l}\text { Protective clothing - performance requirements of chemical protective } \\
\text { clothing }\end{array}$ \\
\cline { 3 - 4 } & GB/T 24540-2009; & Protective clothing-protective clothing against liquid acids and alkalis \\
\cline { 3 - 4 } & GB/T 23462-2009; & $\begin{array}{l}\text { Protective clothing-test method for chemical protective materials to } \\
\text { permeation by } \\
\text { Chemicals }\end{array}$ \\
\hline $\begin{array}{c}\text { Bureau of Indian } \\
\text { Standards (IS) }\end{array}$ & 1986 & IS 15071:2002 & Chemical Protective clothing -Specification \\
\hline
\end{tabular}

\section{Conclusion}

Mankind requires covering himself in appropriate clothing largely to protect him from harsh environmental conditions. A huge labour force is seen to expose itself to cruel working conditions in industries involving handling of a wide range of dangerous and harmful chemicals. A wide variety of chemicals are being used for the process of electroplating. The baths used for plating are either acid baths or alkaline baths. It has been observed that workers handling these compounds are rarely found wearing required protective wear. Occasionally they are seen wearing gloves and boots. As a result they are seen to suffer from skin burn, rash, allergy and such other health conditions. They need to be provided special garments to give them protection against harmful chemicals; garments that are functional, durable, and comfortable and affordable. The workers have lack of education in terms of safety practices. The employers also are not concerned about the safety issues. Developing CPC which is comfortable in terms of mobility, environmental conditions and donning on and off; functional in terms of permeability, penetration and degradation, cost effective and durable is necessary as also bringing an attitudinal change towards using CPC both in employees and employers.

\section{Future Scope}

Relevant to the environmental conditions of Metal Electroplating units at Faridabad the researcher is exploring appropriate fibre, yarn and fabric types and combinations thereof to develop CPC for workers employed in these units.

\section{References}

[1] ASTM,"All Chemical Standards for protective Clothing," ASTM International, West Conshohocken, PA, 2015, www.astm.org

[2] BIS, Indian Standard for Chemical Protective ClothingSpecification IS 15071: 2002 Retrieved from https://law.resource.org.

[3] BS 8428 Protective clothing, "Protection against liquid chemicals-Performance requirements for chemical protective suits with liquid-tight connections between different parts of the clothing for emergency teams" (type 3-ET equipment). London, UK: British Standards Institution, 2004.

[4] BS EN. Protective clothing Standards .London,UK: British Standards Institution, 2015

[5] Gibb HJ, Lee PS, Pinsky PF, Rooney BC (2000a). Clinical findings of irritation among chromium chemical production workers. Am J Ind Med 38(2): 127-131

[6] Gopalakrishnan, D., Nithiyakumar, M. \& Nayak, A, "Development of Chemical Protective Clothing," 2002. Retrieved from February 24 2015, http://www.fibre2fashion.com

[7] Halliday-Bell, J., Palmer, K., and Crane, G, "Health and safety behaviour and compliance in electro plating workshops," Occupational Medicine, 47(4), 237-240, 1997.

[8] ISO, 13.340.10: Protective clothing. Standard Catalogue. TC 94/SC 13 Personal Safety- Protective clothing. Geneva, Switzerland: International organizations for Standardization, 2015.

[9] JIS, "Protective clothing Standards. Tokyo, Japan: Japanese Industrial Standard Association,” 2005.

[10] Joshi TK, Smith KR, "Occupational health in India," Occup Med.17:371-89. III-(4), 2002. [PubMed]

[11] Kartik K, Sharavanan PS, \& Arivalagan , "Effects of Hexavalent Chromium Exposures And Control Measures Through Phytoremediation," International journal of Reciprocal Symmetry and Theoretical physics, 1 (2):111-115, 2014.

[12] Khan, M. M., Halim, Z. I. \& Iqbal, M, "Attributes of occupational injury among workers in the chemical industry and safety issues," International Journal of occupational Safety and Ergonomics, 12 (3), 327-341, 2006.

[13]Leigh J, Macaskill P, Kuosma E, Mandryk J. Global burden of disease and injuries due to occupational factors. Epidemiology. 10, 626-31, 1999. [PubMed]

[14] Li J, Zheng R; Zhou H, Guo J, "Comparative Study of Chinese and International Standard Systems on Chemical Protective Clothing," Journal of Fiber Bioengineering and Informatics, 6:1, 3-75, 2013. doi:10.3993/jfbi03201306

[15] Mauskar, J. M., "Waste Minimisation and Ecofriendly Electroplating Processes," Parivesh, 4-14, 2008.

\section{Volume 4 Issue 12, December 2015}




\section{International Journal of Science and Research (IJSR) \\ ISSN (Online): 2319-7064}

Index Copernicus Value (2013): 6.14 $\mid$ Impact Factor (2014): 5.611

[16] OHCOW, Hexanalent Chromium. Ontario, Canada: Occupational Health Clinics for Ontario Workers Inc., 2005.

[17] OSHA 3151-2R. Personal protective equipment. U.S. Department of Labour

[18] Occupational Safety and Health Administration, 2003.

[19] Pingle SR. Do occupational health services really exist inIndia? Available from:

http://www.occuphealth.fi/NR/rdonlyres/04399102-

514B-4444-AC38-

C90DCC3D9A3D/0/7DoOHservicesreallyexistinIndia.p df.

[20] Sadhra, S., Petts, J., McAlpine, S., Pattison, H., \& MacRae, S, "Workers' understanding of chemical risk: electroplating case study," Occupational \& Enviornmental Medicine, 59, 689-695, 2002 doi:10.1136/oem.59.10.689

[21] Skin Exposures \& Effects, "Centres for Disease Control and Prevention," Atlanta: National Institute for Occupational Safety and Health Education and Information, 2013. Retrieved from http://www.cdc.gov.

[22] Srivastava, S. C, "Occupational Health of Workers in India Law and Practice" The Business Law Journal, 31, 11-42, 2002.

\section{Author Profile}

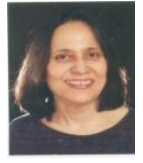

Dr Rita Kant is a Senior Faculty at University institute of fashion technology, Panjab University Chandigarh. She has approximately 24 Years of teaching experience. She has presented some 40 research based paper during this time at National and International conferences, both in India and abroad. She has edited course books and papers in peer reviewed international journals, authored chapters in books and have been an editor of a book and have also authored a book. She has completed several projects and has two projects in hand as well. At present she is supervising seven $\mathrm{PhD}$ scholars two of whom hold JRF Scholarship and five are working as guest faculty in UIFT.

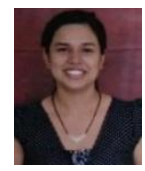

Sugandha Sahni has an overall teaching experience of 10 years as Assistant Professor with various recognized institutions. Presently she is working as Assistant Professor in Amity University, Noida and pursuing Ph.d at Punjab University, Chandigarh. She has written two chapters in a book Titled Inventive Techniques of Refurbishing Discarded Textiles, ISBN: 978-93-83316-20-5, Publisher Gaurav Book Centre Pvt. Ltd. This book is available at Amazon. She has also presented a research paper in an International Conference on Emerging Trends in Management; Fashion \& Footwear Business organized by FDDI, at Rohtak and gave a poster presentation based on my Research at OGTC Conference, at 11TH International Conference on Apparel \& Home Textiles 2015. To have industry knowledge, attended a month long industrial training program at Shahi Exports, Faridabad in 2012.

Volume 4 Issue 12, December 2015 www.ijsr.net 